\title{
ЯЙЦЕНОСНІТЬ ТА МЕДОПРОДУКТИВНІСТЬ БДЖІЛ РІЗНИХ ЛІНІЙНИХ КРОСІВ КАРПАТСЬКОї ПОРОДИ
}

\author{
Петько Марія Сергіївна \\ аспірант \\ Інститут розведення і генетики тварин НАAН ім. М.В. Зубця \\ ORCID: 0000-0002-5375-7889 \\ E-mail: pmarichka777@gmail.com \\ Федорович Віталій Васильович \\ доктор сільськогосподарських наук, старший науковий співробітник \\ Інститут біології тварин НАAН \\ ORCID: 0000-0002-4272-4045 \\ E-mail: lionel@i.ua \\ Федорович Єлизавета Іллівна \\ доктор сільськогосподарських наук, профресор, член-кореспондент НААН \\ Інститут біології тварин НАAН \\ ORCID: 0000-0002-9910-7902 \\ E-mail: logir@ukr.net \\ Мазур Наталія Петрівна \\ доктор сільськогосподарських наук \\ Інститут біології тварин НААН \\ ORCID: 0000-0001-6244-713X \\ E-mail: BabikN@i.ua
}

Перспективним напрямком племінної роботи у бджільниитві є гібридизація та використання міжпородних гібридів, які забезпечують у першому поколінні значне підвищення продуктивності. Не менш важливе значення має розробка та масове впровадження міжлінійних гібридів найбільш цінних порід бджіл та перевірених за потомством ліній. 3 огляду на вищенаведене, метою наших досліджень було вивчити яйценосність та медпродуктивність бджіл різних лінійних кросів карпатської породи. Дослідження проведені на бджолах різних генеалогічних формувань карпатської породи у приватних пасіках в с. Наварія та м. Броди Львівської області. Для проведення експериментальних досліджень було сфрормовано 6 груп по 10 бджолосімей у кожній: I - контрольна група - місцеві бджоли карпатської популяції (тип «Вучківський» - 10 бджолосімей); II - дослідна група - інбредна група ф UA3-5- 9-15.112-2018 х ठิ UA3-5- 9-15.112-2018 (૧ мікропопуляція «915» x ठิ мікропопуляція «915» - 11 бджолосімей); III - дослідна група - селекційний крос о UАЗ-65- 2019 х Оิ UA3-5- 915.112-2018 (ㅇ лінія "Сто» х Оิ мікропопуляція «915» - 10 бджолосімей; IV - дослідна група - селекційний крос ф UA3-5- 352019 x ठิ UA3-5- 9-15.112-2018 (Р Вучківська х Оิ мікропопуляція «915» - 10 бджолосімей); V - дослідна група - селекційний

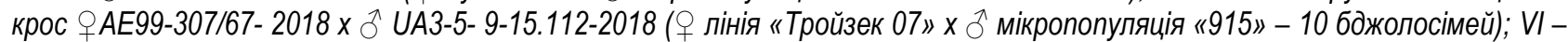

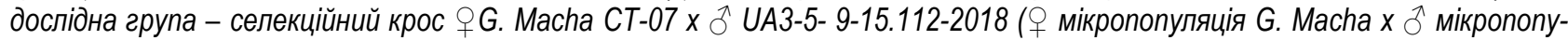
ляція «915» - 10 бджолосімей). Встановлено, що яйценосність бджоломаток максимальних значень досягала у травнічервні. Кращою яйценосністю відзначалися бджоломатки селекційного кросу РАE99-307/67- 2018 х ठิ UA3-5- 9-15.1122018 (ㅇ лінія «Тройзек 07» x ô мікропопуляція «915») у період з 17 по 28 травня 2020 року. За підсумками весняного $i$ літнього медозборів найвищими показниками характеризувалися бджолосім'ї селекційного кросу + G. Macha CT-07 x $\delta$ UA3-5- 9-15.112-2018 (ㅇ мікропопуляція G. Macha х §̊ мікропопуляція «915») - 27,7 ке..

Ключові слова: Карпатська порода бджіл, бджоломатки, бджолосім'ї, міжлінійні кроси, яйценосність, медпродуктивність.

DOI: https://doi.org/10.32845/bsnau.lvst.2020.4.11

Бджільництво - важлива галузь сільського господарства, яка має велике народногосподарське значення для збільшення урожайності ентомофільних культур, поліпшення якості плодів та насіння і збільшення життєздатності рослин наступних поколінь. Крім того, від бджільництва отримують ряд продуктів, що використовуються людиною: мед, віск, прополіс, маточне молочко, квітковий пилок, бджолину отруту. Цінним поживним і дієтичним продуктом $€$ мед [6, ].

Відомо, що продуктивність бджолиних сімей залежить не тільки від умов їх утримання, сили та стану кормової

бази, а й від рівня племінної роботи $[1,12]$. Нажаль, племінна робота у бджільництві поки що залишається однією 3 відстаючих ділянок теоретичної і практичної діяльності. На сьогодні не існує жодної заводської породи бджіл, виведеної в результаті планомірної, цілеспрямованої селекційної роботи. Не існує таких порід і за кордоном. Відсутня також достатня база науково-обгрунтованих даних щодо порівняльної оцінки місцевих і закордонних примітивних порід у різних природо-економічних зонах, хоча існують значні відмінності у зимостійкості, плодовитості, особливостях розвитку, флороспеціалізації, медовій та восковій продуктивності 
та ефективності запилення сільськогосподарських культур бджолами різних порід у різних природних умовах. Тому, важливу роль у підвищенні продуктивності пасік має науково обґрунтований вибір порід бджіл у відповідності до місцевих природно-економічних умов і характеру медозбору [1].

Для прогнозування інтенсивності розвитку, визначення стану бджолиних сімей, оцінки відтворної здатності маток здійснюють облік кількості розплоду у їх гніздах $[2,10]$

Перспективним напрямком племінної роботи у бджільництві $€$ гібридизація та використання міжпородних гібридів, які забезпечують у першому поколінні значне підвищення продуктивності $[8,14]$. Не менш важливе значення має розробка та масове впровадження міжлінійних гібридів найбільш цінних порід бджіл та перевірених за потомством ліній $[3,5]$.

Численні дослідження свідчать, що в кожній природно-кліматичній зоні необхідно використовувати пристосовані до місцевих умов типи та лінії бджіл. Без урахування цього фактора досягнути бажаного ефекту гетерозису буде неможливо. Нові генеалогічні формування необхідно всесторонньо оцінювати і виявляти кращі з них, що дасть підвищити продуктивність бджіл [7, 9].

3 огляду на вищенаведене, метою наших досліджень було вивчити яйценосність та медпродуктивність бджіл різних лінійних кросів карпатської породи.

Матеріали та методи досліджень. Експериментальні дослідження проведені на бджолах різних генеалогічних формувань лінійних кросів карпатської породи у приватних пасіках в с. Наварія Львівської області.

Для проведення експериментальних досліджень було сформовано 6 груп по 10 бджолосімей у кожній:

I - контрольна група - місцеві бджоли карпатської популяції (тип «Вучківський» - 10 бджолосімей).

II - дослідна група - інбредна група фUA3-5- 915.112-2018 x ₹ै UA3-5- 9-15.112-2018 ( мікропопуляція «915» х ठૈ мікропопуляція «915»-11 бджолосімей).

III - дослідна група - селекційний крос фUA3-65-

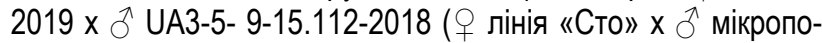
пуляція «915» - 10 бджолосімей).
IV - дослідна група - селекційний крос фUA3-5- 35-

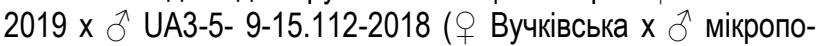
пуляція «915» - 10 бджолосімей).

V - дослідна група - селекційний крос фАЕ99307/67- 2018 x §ิ UA3-5- 9-15.112-2018 (ф лінія «Тройзек 07» x ठै мікропопуляція «915» - 10 бджолосімей).

VI - дослідна група - селекційний крос $\propto \mathrm{G}$. Macha CT-07 x ðૈ UA3-5- 9-15.112-2018 ( мікропопуляція G. Macha x ठิ мікропопуляція «915»-10 бджолосімей).

Кількість запечатаного розплоду в гнізді замірювали кожні 12 днів за допомогою рамки-сітки з квадратами розміром 5x5 см, що дорівнює 100 коміркам [4]. Період обліку тривав з 17.03 до 14.09. 2020 р. Для обліку запечатаного розплоду оглядали усі рамки гнізда сім'ї, на яких він зосереджений. На кожну із сторін стільника прикладали рамку-сітку і підраховували спочатку кількість цілих квадратів із розплодом. Ті квадрати, у яких комірки частково зайняті розплодом, перераховували у цілі.

Порахувавши за допомогою рамки-сітки загальну кількість квадратів, зайнятих запечатаним розплодом, одержану цифру множили на відповідну кількість комірок. Поділивши суму комірок, зайнятих запечатаним розплодом у сім'ї за один облік на 12 (стадія передлялечки і лялечки бджоли триває 12 діб), визначали добову яйценосність матки. Отриманий результат стосується періоду, що минув 21 день тому і закінчився за 9 днів до обліку (розплід робочих бджіл).

Медову продуктивність бджолосімей за весняний та літній періоди визначали зважуючи разом до і після відкачування меду всі відібрані з гнізда бджолиної сім'ї стільники.

Статистичну обробку результатів досліджень проводили за допомогою програм Microsoft Excel та "Statistica 6.1" за Г.Ф. Лакиным [11]. Різницю між показниками вважали вірогідною при $\mathrm{P}<0,05\left(^{*}\right), \mathrm{P}<0,01\left(^{* *}\right), \mathrm{P}<0,001\left(^{* * *}\right)$.

Результати дослідження. Результати наших досліджень свідчать, що яйценосність маток під час весняного розвитку у всіх групах стрімко збільшується і досягає максимуму у травні та червні, пізніше поступово зменшується (табл.1)

Таблиця 1

Динаміка яйценосності бджоломаток, $\mathrm{M \pm m}(\mathrm{n}=10)$

\begin{tabular}{|c|c|c|c|c|c|c|}
\hline \multirow{2}{*}{$\begin{array}{c}\text { Теріод яйценосності у } \\
2020 \text { p. }\end{array}$} & \multicolumn{6}{|c|}{ Група бджоломаток } \\
\hline & $\mathrm{I}$ & II & III & IV & $\mathbf{V}$ & VI \\
\hline $17.03-28.03$ & $340,8 \pm 14,48$ & $269,4 \pm 4,81^{* * *}$ & $375,1 \pm 17,93$ & $419,3 \pm 18,52^{\star *}$ & $300,0 \pm 14,63$ & $317,8 \pm 15,74$ \\
\hline $29.03-9.04$ & $637,8 \pm 33,11$ & $760,8 \pm 34,93^{*}$ & $661,8 \pm 12,73$ & $844,5 \pm 33,56^{\star \star \star}$ & $641,7 \pm 30,37$ & $661,1 \pm 35,61$ \\
\hline $10.04-21.04$ & $931,3 \pm 35,36$ & $1027,6 \pm 41,36$ & $939,3 \pm 24,15$ & $1197,1 \pm 57,58^{\star \star \star}$ & $946,6 \pm 48,97$ & $1092,9 \pm 52,78^{*}$ \\
\hline $22.04-04.05$ & $1202,2 \pm 56,34$ & $1483,9 \pm 87,68^{*}$ & $1205,4 \pm 39,42$ & $1385,3 \pm 45,00^{*}$ & $1302,1 \pm 64,97$ & $1215,6 \pm 61,84$ \\
\hline $05.05-16.05$ & $1592,6 \pm 87,25$ & $1668,2 \pm 62,84$ & $1513,1 \pm 86,23$ & $1546,2 \pm 88,75$ & $1441,3 \pm 57,43$ & $1324,5 \pm 79,71^{*}$ \\
\hline $17.05-28.05$ & $1648,2 \pm 68,75$ & $1708,1 \pm 58,08$ & $1634,0 \pm 105,20$ & $1729,7 \pm 53,01$ & $1738,5 \pm 59,51$ & $1610,2 \pm 32,10$ \\
\hline $29.05-9.06$ & $1701,5 \pm 67,62$ & $1682,1 \pm 51,53$ & $1712,3 \pm 83,97$ & $1623,7 \pm 66,63$ & $1691,0 \pm 72,37$ & $1575,9 \pm 34,45$ \\
\hline $10.06-22.06$ & $1534,6 \pm 84,34$ & $1531,2 \pm 15,29$ & $1533,1 \pm 109,08$ & $1621,2 \pm 52,84$ & $1549,8 \pm 88,27$ & $1499,6 \pm 57,61$ \\
\hline 22.06- 3.07 & $1227,5 \pm 118,62$ & $1500,9 \pm 59,93$ & $1544,3 \pm 115,64$ & $1552,6 \pm 50,72^{*}$ & $1354,9 \pm 65,50$ & $1463,6 \pm 41,50$ \\
\hline $4.07-15.07$ & $1179,6 \pm 110,14$ & $1469,9 \pm 13,67^{*}$ & $1464,2 \pm 93,73$ & $1423,7 \pm 64,99$ & $1295,0 \pm 66,67$ & $1324,4 \pm 33,13$ \\
\hline $16.07-27.07$ & $1121,7 \pm 65,63$ & $1175,4 \pm 51,89$ & $1008,5 \pm 60,65$ & $1173,3 \pm 29,04$ & $1072,7 \pm 30,96$ & $1264,5 \pm 100,77$ \\
\hline 28.07-8.08 & $876,3 \pm 102,92$ & $1069,6 \pm 69,54$ & $908,9 \pm 59,99$ & $975,0 \pm 12,59$ & $928,8 \pm 67,02$ & $1130,8 \pm 38,22^{*}$ \\
\hline $9.08-20.08$ & $736,1 \pm 68,68$ & $915,5 \pm 28,49^{*}$ & $688,9 \pm 64,38$ & $897,6 \pm 10,43^{*}$ & $741,7 \pm 27,91$ & $950,0 \pm 13,33^{* *}$ \\
\hline 21.08- 1.09 & $515,3 \pm 42,38$ & $453,9 \pm 27,21$ & $518,8 \pm 11,29$ & $567,0 \pm 30,26$ & $486,8 \pm 16,75$ & $485,9 \pm 18,62$ \\
\hline $2.09-14.09$ & $294,5 \pm 17,07$ & $277,8 \pm 17,48$ & $204,3 \pm 13,28$ & $346,9 \pm 12,97^{*}$ & $241,6 \pm 26,51$ & $377,4 \pm 9,31^{* * *}$ \\
\hline
\end{tabular}

Примітка. Вірогідність різниці між показниками у иій і наступній таблиці вказана при порівнянні з I (контрольною) групою

У контрольній групі яйценосність маток знаходилася в межах 294,5-1701,5 яєць за добу, при цьому найвищою вона була у період з 29 травня по 9 червня (1701,5 шт.). У цей проміжок часу найвищий показник яйценосності відміче- 
но також у бджоломаток третьої групи (1712,3 шт.). У бджіл всіх інших груп найвищий показник яйценосності зафіксовано у період з 17 по 28 травня. Так, у бджоломаток другої групи він становив 1708,1, четвертої - 1729,7, п'ятої 1738,5 і шостої - 1610,2 яєць за добу. Втім, варто зазначити, що за яйценосністю різниця між бджоломатками контрольної і дослідних груп у досліджувані періоди здебільшого була невірогідною, а з матками третьої і п'ятої груп - вірогідність не відмічена в жодному випадку.
Встановлено, що найкращі результати по весняному збору меду відмічено у бджіл четвертої групи - 10,5 кг, що на 1,5 кг більше, ніж у бджолосімей контрольної групи (табл. 2). Найбільший показник літнього медозбору встановлено у бджіл кросу 9 G. Macha CT-07 x § UA3-5- 9-15.1122018 - 17,5 кг. У бджолосімей цього кросу відмічена і найбільша кількість меду за підсумками весняного і літнього медозборів $(27,7$ кг).

Медопродуктивність бджолосімей $(\mathrm{n}=10)$

\begin{tabular}{|c|c|c|c|c|c|c|}
\hline \multirow{2}{*}{ Група бджіл } & \multicolumn{2}{|c|}{ Весняний медозбір, кг } & \multicolumn{2}{|c|}{ Літній медозбір, кг } & \multicolumn{2}{|c|}{ Загальний медозбір, кг } \\
\hline & $\mathrm{M} \pm \mathrm{m}, \mathrm{kr}$ & Cv, \% & $\mathrm{M} \pm \mathrm{m}, \mathrm{kr}$ & Cv, \% & $\mathrm{M} \pm \mathrm{m}, \mathrm{kr}$ & Cv, $\%$ \\
\hline 1 & $9,0 \pm 0,17$ & 5,7 & $13,4 \pm 0,51$ & 11,3 & $22,4 \pm 0,55$ & 7,4 \\
\hline II & $10,4 \pm 0,24^{* \star}$ & 6,9 & $15,6 \pm 0,33^{* *}$ & 6,4 & $26,0 \pm 0,52^{\star *}$ & 6,0 \\
\hline III & $10,0 \pm 0,42$ & 12,4 & $14,6 \pm 0,49$ & 10,0 & $24,6 \pm 0,84$ & 10,2 \\
\hline IV & $10,5 \pm 0,34^{* \star}$ & 9,6 & $14,8 \pm 1,03$ & 20,8 & $25,4 \pm 1,29$ & 15,2 \\
\hline V & $10,0 \pm 0,36^{*}$ & 10,9 & $16,9 \pm 0,99^{*}$ & 17,7 & $26,9 \pm 1,33^{*}$ & 14,9 \\
\hline $\mathrm{VI}$ & $9,8 \pm 0,36$ & 11,0 & $17,5 \pm 1,23^{\star *}$ & 21,1 & $27,7 \pm 1,21^{\text {** }}$ & 13,1 \\
\hline
\end{tabular}

Втім, достовірна перевага за медпродуктивністю як за весняний, так і за літній медозбори над бджолами контрольної групи була відмічена лише у бджолосімей другої групи - відповідно на 1,4 та 2,2 кг при $P<0,01$ у обох випадках та п'ятої групи - на 1,01 $(P<0,05)$ і 3,5 кг $(P<0,05)$. Бджоли четвертої групи достовірно $(\mathrm{P}<0,01)$ переважали особин контрольної лише за медпродуктивністю весняного медозбору - на 1,5, а шостої - літнього - на 4,1 кг.

Загальний збір меду за весь досліджуваний період, залежно від групи, коливався від 22,4 ( контрольна група) до 22,7 кг (шоста група).

Таким чином, між бджолами різних внутрішньопородних кросів карпатської популяції спостерігалися певні відмінності за показниками відходу бджіл, загальних витрат кормів за зимівлю та в розрахунку на 1 кг бджіл. Найменше корму за зиму спожили бджолосім'ї шостої групи, проте в розрахунку на 1 кг бджіл найнижчі результати відмічені у бджіл третьої групи. Кращою зимостійкістю характеризувалися бджоли, отримані від поєднання самок і самців мікро- популяції «915», гігієнічною поведінкою через 12 і 24 годин після пошкодження розплоду - бджолосім'ї другої і п'ятої груп відповідно, яйценосністю - бджоломатки п'ятої групи у період з 17 по 28 травня 2020 року. За підсумками весняного і літнього медозборів найвищими показниками характеризувалися бджолосім'ї селекційного кросу + G. Macha CT-07 x ठิ UA3-5- 9-15.112-2018 (27,7 кг).

Висновки. 1. Встановлено, що яйценосність бджоломаток максимальних значень досягала у травні-червні. Кращою яйценосністю відзначалися бджоломатки селекційного кросу $+A E 99-307 / 67-2018$ х $\precsim$ UA3-5- 9-15.112-2018 ( лінія «Тройзек 07» х ठิ мікропопуляція «915») у період 3 17 по 28 травня 2020 року.

2. За підсумками весняного і літнього медозборів найвищими показниками характеризувалися бджолосім"ї селекційного кросу $\bigcirc \mathrm{G}$. Macha CT-07 x $\curvearrowright$ UA3-5- 9-15.1122018 (q мікропопуляція G. Macha x $\hat{\sigma}$ мікропопуляція «915»).

\section{Список використаної літератури:}

1. Богдан М. К., Кірович Н. О. Ясько В. М., Петренко С. О., Котляр Є. О. Селекція та розведення бджіл. Київ.: «Кондор», 2018. 227 с.

2. Броварський В., Бріндза В., Отченашко В., Повозніков М., Адамчук Л. Методика дослідної справи у бджільництві. Київ: Видавничий дім «Вініченко», 2017. 166 с.

3. Гайдар В. А., Сахацький М. І., Папп В. В. Селекційно-племінна робота з карпатськими бджолами внутрішньопородного типу «Синевир» [Електронний ресурс]. Наукові доповіді НУБіП України Режим доступу до журн. : http://archive.nbuv.gov.ua/e-journals/nd/2012_5/12smi.pdf. 2012. № 34. 11 c.

4. Гайдар В. А. Карпатские пчелы. Ужгород: Карпаты, 1989. 318 с.

5. Гайдар В. А. Пилипенко В. В. Три типи карпатських бджіл визнані як селекційне досягнення. Пасіка. 2010. № 3, С. $55-64$.

6. Єфіменко Т. М., Односум Г. В. Нагальні проблеми бджільництва в Україні.. Бджільництво України. 2017. Вип. 2, С.

7. Керек С.С. Влияние эффекта гетерозиса на медовою продуктивность карпатских пчел и их помесей. Ученые записки ВГАВМ. 2017. Т. 5. Вып. 4, С. 110-115.

8. Керек С.С. Ефективність використання міжтипових гібридів карпатських бджіл. Науковий вісник Національного аграрного університету. 2006. № 4, С. $93-100$.

9. Керек С. С., Рубан С. Ю. Комбінаційна здатність карпатськи бджіл типу «Вучківський». Тваринництво України. 2020. № 2, С. 18-23.

10. Ковальский Ю. В., Ковальська Л. М. Особливості розведення карпатських бджіл Features breeding carpathian bees. Науковий вісник Львівського національного університету ветеринарної медицини та біотехнологій імені СЗ ґжицкого. Т. 18. № 1-3, С. 60-64. 
11. Лакин Г. Ф. Биометрия. М.: Высшая школа, 1990. 352 с.

12. Папп В. В., Гайдар В. А. Сахацький М.І. Ефективність відбору сімей карпатських бджіл до селекційного ядра пасіки. Науковий вісник Національного університету біоресурсів і природокористування України. Сер.: Технологія виробництва і переробки продукції тваринництва. № 179, С. 75-79.

13. Папп В. В., Керек С. С. Нова ефективна методика селекції бджіл в умовах Закарпаття. Бджільництво України. № 1, C. $98-102$.

14. Папп В. В., Кізман-Байза А. А., Плиска В. М. Оцінка простих міжтипових гібридів карпатських бджіл в парі поєднань Синевир та Вучківського. Бджільництво України. 2017. № 2, С. 158-165.

15. Продукти бджільництва, їх зберігання та переробка. Бджільницво. [Електронний ресурc] URL: http://pasika.org.ua (дата звернення 20.11.2020).

\section{References:}

1. Bohdan M.K., Kirovych N.O. Yasko V.M., Petrenko S.O. and Kotliar Ye.O., 2018. Selektsiia ta rozvedennia bdzhil [Selection and beeke eping]. Kyiv.: «Kondor».

2. Brovarskyi V., Brindza V., Otchenashko V., Povoznikov M. and Adamchuk L., 2017. Metodyka doslidnoi spravy u bdzhilnytstvi [Methods of research in beekeeping]. Kyiv: "Vinichenko" Publishing House.

3. Haidar V. A., Sakhatskyi M. I. and Papp V. V., 2012. Selektsiino-pleminna robota z karpatskymy bdzholamy vnutrishnoporodnoho typu «Synevyr» [Selection and breeding work with Carpathian bees of interbreed type "Synevyr"]. Naukovi dopovidi NUBiP Ukrainy. No 34, p.11. [Electronic resource]. Rezhym dostupu: http://archive.nbuv.gov.ua/e-journals/nd/2012_5/12smi.pdf.

4. Gaydar V. A., 1989. Karpatskie pchelyi [Carpathian bees]. Uzhgorod: Karpatyi.

5. Haidar V. A. and Pylypenko V. V., 2010. Try typy karpatskykh bdzhil vyznani yak selektsiine dosiahnennia [Three types of Carpathian bees are recognized as a selection achievement]. Pasika. no 3, pp. 8-9.

6. YefimenkoT. M. and Odnosum H. V. 2017. Nahalni problemy bdzhilnytstva v Ukraini [Urgent problems of apiculture in Ukraine]. Bdzhilnytstvo Ukrainy. Vol. 2, pp. 55-64.

7. Kerek S. S., 2017. Vliyanie effekta geterozisa na medovuyu produktivnost karpatskih pchel i ih pomesey [Influence of heterosis effect on honey productivity of Carpathian bees and their hybrids]. Uchenyie zapiski VGAVM. Vol. 5 (4), pp. 110-115.

8. Kerek S. S., 2006. Efektyvnist vykorystannia mizhtypovykh hibrydiv karpatskykh bdzhil [ Efficiency of using intertype hybrids of Carpathian bees]. Naukovyi visnyk Natsionalnoho ahrarnoho universytetu, no 4, pp. 93-100.

9. Kerek S. S. and Ruban S. Yu., 2020. Kombinatsiina zdatnist karpatskyh bdzhil typu «Vuchkivskyi» [Combination ability of Carpathian bees of the Vuchkivskyi type]. Tvarynnytstvo Ukrainy. № 2, pp. 18-23.

10. Kovalskyi Yu. V. and Kovalska L. M., 2016. Osoblyvosti rozvedennia karpatskykh bdzhil [Features breeding carpathian bees]. Naukovyi visnyk Lvivskoho natsionalnoho universytetu veterynarnoi medytsyny ta biotekhnolohii imeni S.Z.Gzhytskoho. T.18. No 1 (65), pp. 60-64.

11. Lakyn H. F. 1990. Byometryia [Biometrics]. M.: Vysshaia shkola

12. Papp V. V., Haidar V. A. and Sakhatskyi M. I., 2012. Efektyvnist vidboru simei karpatskykh bdzhil do selektsiinoho yadra pasiky [Efficiency of selection of families of Carpathian bees to the selection kernel of the apiary]. Naukovyi visnyk Natsionalnoho universytetu bioresursiv i pryrodokorystuvannia Ukrainy. Ser.: Tekhnolohiia vyrobnytstva i pererobky produktsii tvarynnytstva. No 179 , pp. $75-79$.

13. Papp V. V. and Kerek S. S., 2012. Nova efektyvna metodyka selektsii bdzhil v umovakh Zakarpattia [A new effective method of bee selection in Transcarpathia]. Bdzhilnytstvo Ukrainy. No 1, pp. 98-102.

14. Papp V. V., Kizman-baiza A. A. and Plyska V. M., 2017. Otsinka prostykh mizhtypovykh hibrydiv karpatskykh bdzhil v pari poiednan Synevyr ta Vuchkivskoho [Assessment of simple intertypicalhybrids of carpathian bees paired combinations of Synevyr and Vuchkivskij types]. Bdzhilnytstvo Ukrainy, no 2, pp. 158-165.

15. Produkty bdzhilnytstva, yikh zberihannia ta pererobka [Bee products, their storage and processing]. Bdzhilnytsvo. [Elektronnyi resurs]. Rezhym dostupu: http://pasika.org.ua (data zvernennia 20.11.2020). Ukraine)

Petko Mariya Serhiyvna, Graduate student, Institute of Animal Breeding and Genetics nd. a. M.V.Zubets of NAAS (Kyiv,

Fedorovych Vitaliy Vasylyovych, Doctor of Science in Agriculture, senior associate, Institute of Animal Biology NAAS

Fedorovych Yelysaveta Illivna, Doctor of Science in Agriculture, professor, corresponding member of NAAS, Institute of Animal Biology NAAS

Mazur Nataliya Petrivna, Doctor of Science in Agriculture, Institute of Animal Biology NAAS

(Lviv, Ukraine)

Egg production and honey productivity of different linear bees cross of carpathian breed

A promising area of breeding work in beekeeping is hybridization and the use of interbreed hybrids that provide in the first generation significant increase of productivity. Equally important is the development and mass introduction of interlinear hybrids of the most valuable breeds of bees and examined by offspring of lines. Given the above, the aim of our research was to study egg production and honey productivity of bees of different linear crosses of Carpathian breed. Studies have been conducted on bees of different genealogical formations of the Carpathian breeds in private apiaries in the village Navariya and town Brody of Lviv region. For experimental studies, 6 groups of 10 bee families in each were formed: I - control group - local bees of the Carpathian population

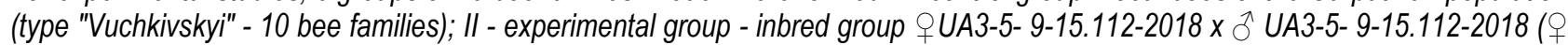


micropopulation "915" x ठิ micropopulation "915" - 11 bee families); III - experimental group - selection cross $q$ UA3-65- 2019 x $\widehat{\sigma}$ UA3-5- 9-15.112-2018 (q line "Sto" x ठ̊ micropopulation "915" - 10 bee families; IV - research group - selection cross 9 UA3-5- 352019 x §ิ UA3-5- 9-15.112-2018 ( Vuchkivska x ふ̋micropopulation "915" - 10 bee families); V - experimental group - selection

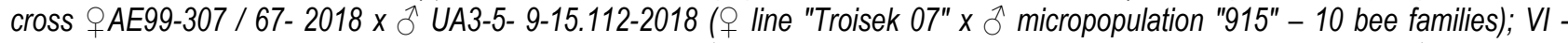
experimental group - selection cross + G. Macha ST-07 x $\partial^{\lambda}$ UA3-5- 9- 5.112-2018 (+ micropopulation of G. Macha x $\hat{\partial}$ micropopulation "915" - 10 bee families). It was found that the egg production of queen bees reached maximum values in May-June. The best

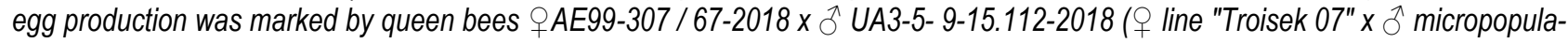
tion "915") in the period from May 17 to 28, 2020. Following the results of spring and summer honey collections the highest indicators were characterized by bee families of breeding cross $q$ G. Macha ST-07 x ठUA3-5- 9-15.112-2018 (G. micropopulation G. Macha x ô micropopulation "915") - 27.7 kg.

Key words: Carpathian breed of bees, queen bees, bee families, interlinear crosses, egg production, honey productivity.

Дата надходження до редакції: 15. 10.2020 р. 